Bulletin of Pharmaceutical Sciences
Assiut University
Website: http://bpsa.journals.ekb.eg/
e-mail: bullpharm@aun.edu.eg

\title{
ANTI-HYPERGLYCEMIC ACTIVITY OF TOTAL ETHANOLIC FRUIT EXTRACT OF FAIDHERBIA ALBIDA ON NICOTINAMIDE- STREPTOZOTOCIN-INDUCED DIABETIC MICE
}

\author{
Rania A. Abdel-Emam ${ }^{1}$, Marwa M. Mohammed ${ }^{2}$, Ahmed A. Ali ${ }^{2}$, Ezz-eldin K. Desoky ${ }^{2}$ and \\ Lourin G. Malak ${ }^{2 *}$ \\ ${ }^{1}$ Department of Pharmacology, Faculty of Medicine, Assiut University, Assiut 71515, Egypt \\ ${ }^{2}$ Department of Pharmacognosy, Faculty of Pharmacy, Assiut University, Assiut 71526, Egypt
}

\begin{abstract}
Faidherbia albida is one of the plants that have been traditionally used throughout the world in the treatment of diabetes. In previous studies, various parts of the plant such as the methanolic root bark, aqueous seed, and the aqueous stem bark extracts have been tested on alloxan-induced diabetic rats for their anti-hyperglycemic activity. In the current study, the antihyperglycemic activity of the total ethanolic extract of Faidherbia albida fruits was evaluated in nicotinamide-streptozotocin-induced diabetic mice using glimepiride as a reference anti-diabetic drug. The total ethanolic fruit extract at $200 \mathrm{mg} / \mathrm{kg}$ body weight significantly $(p<0.05)$ lowered the blood glucose level in diabetic mice by (74\%) after 4 hrs of oral administration while the peak hypoglycemic effect of glimepiride (55.2\%) occurred at the 4th hr after oral administration. The results provided evidence that Faidherbia albida fruit extract is recommended to be used as a hypoglycemic drug in treating diabetic patients.
\end{abstract}

\section{INTRODUCTION}

Diabetes mellitus (DM) is a chronic debilitating metabolic disease characterized by an elevation in blood glucose levels due to defects in insulin secretion, insulin action, or both $^{1}$. Diabetes is typically divided into 2 major subtypes, type 1 and type 2 . The pathophysiologic defects that characterize type 2 diabetes mellitus (T2DM) include insulin resistance in the liver, skeletal muscle, and adipose tissue, and impaired insulin secretion by pancreatic $\beta$ cells ${ }^{2}$.

The currently available antidiabetic drugs manage the blood glucose levels under normal range by supplementing insulin, improving insulin sensitivity, increasing insulin secretion from the pancreas, decreasing glucose absorption from the intestinal tract, and/or glucose uptake by tissue cells ${ }^{3}$. Glimepiride is a long-acting $2^{\text {nd }}$ generation sulfonylurea, used in the treatment of T2DM, acts mainly by stimulating insulin release from the pancreatic $\beta$-cells and improves insulin resistance in peripheral target tissues such as muscle and fat $^{4}$.

The available antidiabetic drugs have a diverse of adverse side effects, decreased efficacy over time, and are expensive ${ }^{5}$. Therefore, searching for and developing new antidiabetic drugs from natural plant sources have been a great interest in research work today. Many medicinal plants have been recommended for the treatments of DM because of their effectiveness, fewer side effects, and relatively low cost ${ }^{6}$. One such plant used traditionally in managing DM is the Acacia albida.

Acacia albida (Leguminosae) is characterized by the absence of conspicuous glands on leaf-rachis and the presence of apical stalked glands on anthers. This led to the segregate of Acacia albida Delile into a new mono-specific genus Faidherbia albida Chev. ${ }^{7}$.

Faidherbia albida is native to Africa, the Middle East, and Asia. In Egypt, it is found in the flora of the Nile valley and the Eastern Desert ${ }^{7}$. It has grey to whitish bark "hence the 
name albida", smooth when young, fissured, flaky and cork-like when matured ${ }^{8}$. It is employed traditionally to treat medical disorders such as fever, diarrhea, urticaria, vomiting, cough, rheumatism, and hemorrhage $^{7 \& 9}$. Previous studies have shown that $F$. albida possess anti-microbial ${ }^{10}$, antipyretic, and anti- inflammatory effects ${ }^{9}$.

A previous ethnobotanical survey conducted by Shinkafi et al. (2015) documented acacia albida as one of the medicinal plants used traditionally as antidiabetic in Nigeria ${ }^{11}$. Moreover, Mohammed et al. (2014) reported Acacia albida as one of the medicinal plants explored for folkloric or traditional use in the treatment of diabetes mellitus ${ }^{12}$. Anti-hyperglycemic activities have been reported for various parts of $F$. albida such as methanolic root bark extract $^{13}$, aqueous seed extract ${ }^{14}$, aqueous stem bark extract ${ }^{15}$. Moreover, Kashimawo and his colleagues, (2017) tested the crude extract and fractions of the stem bark of $F$. albida in alloxan-induced diabetic rats ${ }^{16}$.

Considering the lack of published experimental studies evaluating the effects of the fruit extract of $F$. albida in diabetic animal models, this provoked us to evaluate the possible anti-hyperglycemic activity of the total ethanolic fruit extract of $F$. albida in nicotinamide-streptozotocin-induced diabetic mice.

\section{MATERIALS AND METHODS}

\section{Drugs and chemicals}

Streptozotocin (STZ) was purchased from MP Biomedicals, LLC., France while nicotinamide (NA) was purchased from Alpha Chem., India. Glimepiride was given as a gift in its refined powder form from Medical Union Pharmaceuticals CO., S.A.E. Other chemicals used in this study as carboxy methylcellulose (CMC) were of analytical grade and procured from El Nasr Pharmaceutical chemical CO., Egypt.

\section{Extract}

Faidherbia albida total ethanolic fruit extract.

\section{Plant source and authentication}

The plant material used in this study is dried pods of $F$. albida (Del.) A. Chev. (Acacia albida (Del.)). It was collected during the fruiting stage in the period of September to December 2013 from the fields of Komombo garden of medicinal plant, Aswan, Egypt. The plant was kindly identified and authenticated by Prof. Dr. Kotb Amer, Professor of Taxonomy, Botany Department, Faculty of Science, Assiut University. A specimen of the plant is deposited in the herbarium of the Department of Pharmacognosy, Faculty of Pharmacy, Assiut University with voucher number 3/2019.

\section{Extraction}

The air-dried almost deseeded pods were extracted by maceration with $70 \%$ ethanol at room temperature till exhaustion. The ethanolic extracts were combined together and concentrated under reduced pressure and left to dry then weighed. The dried pod extract was dissolved in a $0.5 \%$ CMC solution for injection.

\section{Experimental animals}

This study was conducted on adult male albino mice. Animals were obtained from the animal house of the Faculty of Medicine, Assiut University. Their weight ranged between 15-20 grams and their age ranged between 8-12 weeks. Mice were housed in groups in clean capacious cages under standard laboratory conditions including a good aerated room with suitable temperature $\left(25 \pm 5^{\circ} \mathrm{C}\right)$, maintained at good light. They were fed with standard rodent food and had free access to water.

\section{Animal ethics}

The research was conducted in accordance with the internationally accepted principles for laboratory animal use and care as found in the European Community guidelines (EEC Directive of 1986; 86/609/EEC). All experimental procedures applied in this study were applicable to the institutional guidelines for the care and use of animals in the Faculty of Medicine, Assiut University.

\section{Acute toxicity study}

The acute toxicity tests of the total ethanolic fruit extract were determined according to the protocol described by Lorke ${ }^{17}$ to determine the median lethal dose $\left(\mathrm{LD}_{50}\right)$. 
The experiment was carried out in two phases; the first phase involved an initial dosefinding procedure, in which the animals were divided into three groups (3 mice/group) for each given dose. Doses of 10, 100, and 1000 $\mathrm{mg} / \mathrm{kg}$ were administered intra-peritoneal. The treated animals were monitored for $24 \mathrm{hrs}$ for mortality and general behavior. The second phase was based on the result of the above step, in which the animals were divided into three groups (1 mouse/group) and given doses 1600 , 2900 , and $5000 \mathrm{mg} / \mathrm{kg}$ intra-peritoneal. The treated animals were again monitored for 24 hrs. The $\mathrm{LD}_{50}$ was calculated based on the results of the second phase as the square root of the product of the lowest lethal dose and the highest non-lethal dose ${ }^{17}$. Toxicity signs were characterized by irritability, writhing, hypothermia, loss of motor coordination, sedation, and deep sleep, followed by death.

\section{Experimental design}

In the present study, mice were divided into the following groups; each consisting of 6 mice. Group I: Control non-diabetic mice. Negative control ( $0.5 \%$ CMC solution). Group II: Control diabetic, non-treated $(0.5 \% \mathrm{CMC}$ solution). Group III: Diabetic treated with glimepiride $(2.5 \mathrm{mg} / \mathrm{kg}$ oral). Group IV, V and VI served as diabetic mice treated with total ethanolic extracts of fruits TF-1 $(100 \mathrm{mg} / \mathrm{kg})$, TF-2 $(200 \mathrm{mg} / \mathrm{kg})$ and TF-3 (300 mg/kg) intraperitoneal (I.P.) respectively.

\section{Experimental induction of diabetes}

Type 2 diabetes was induced in mice by a combination of streptozotocin and nicotinamide. The mice administered NA (110 $\mathrm{mg} / \mathrm{kg}$, I.P.) dissolved in saline $15 \mathrm{~min}$ before STZ (65 mg/kg, I.P.). Streptozotocin was freshly prepared just before injection and dissolved in $50 \mathrm{mM}$ sodium citrate buffer $(\mathrm{pH}$ 4.5). Type 2 diabetes was assured $72 \mathrm{hrs}$ later by measurement of the blood glucose. Blood glucose levels in NA/STZ-treated mice were consistently $>200 \mathrm{mg} / \mathrm{dl}^{18}$.

\section{Blood glucose estimation}

Fasting blood glucose estimation was done using the glucometer (FreeStyle Freedom ${ }^{\circledR}$ Lite glucometer, TheraSense, Inc., U.S.A.). Blood sampling was done via the tail incision method. A drop of blood collected from the tail vein was gently applied over the test zone of the glucometer and the blood glucose level was recorded immediately as $\mathrm{mg} / \mathrm{dl}$. After administration of glimepiride and the total ethanolic fruit extract, blood samples were collected from the vein at $0,1,2,3$ and $4-\mathrm{hr}$ intervals for blood glucose estimation.

\section{Data analysis}

Statistical analysis was done using the computer software Graphpad Prism 5.0. Data were expressed as the mean \pm standard error (SE) of the means for each group. When two groups were compared, unpaired $t$-test was used. The difference was insignificant at $p$ value $>0.05$, significant at $p$-value $<0.05$. The results obtained from 'test' mice treated with $F$. albida fruit extract and glimepiride were compared with the diabetic control group by one way analysis of variance (ANOVA). Analyses revealing $p$-values $<0.05$ were deemed to be statistically significant.

\section{RESULTS AND DISCUSSION}

\section{Results \\ Acute toxicity results}

The acute toxicity study revealed no mortality when total ethanolic $F$. albida fruit extract was administered at doses lower than $1600 \mathrm{mg} / \mathrm{kg}$. Mortality was observed in mice injected with $2900 \mathrm{mg} / \mathrm{kg}$.

\section{Anti-diabetic activity}

The blood glucose level was analyzed from a tail-vein blood sample (by cutting the tail-tip of the mice) at intervals of $0,1,2,3$, and $4 \mathrm{hrs}$ and results were reported as $\mathrm{mg} / \mathrm{dl}$ as shown in table 1.

The mice were deemed to be diabetic after 72 hrs of treatment with NA and STZ. This was evidenced by the significant $(p<0.05)$ elevation in the fasting blood glucose level as compared with the control non-diabetic mice. Treatment of diabetic mice with the reference antidiabetic drug (glimepiride $2.5 \mathrm{mg} / \mathrm{kg}$ ) caused a gradual significant $(p<0.05)$ reduction in the blood glucose level in comparison with the control diabetic mice. The peak of its hypoglycemic effect (55.2\%) occurred at the $4^{\text {th }} \mathrm{hr}$ after oral administration.

Treatment of diabetic mice with 100 and $200 \mathrm{mg} / \mathrm{kg}$ of total ethanolic fruit extract of $F$. albida caused a significant $(p<0.05)$ reduction in the blood glucose level at the $2^{\text {nd }}, 3^{\text {rd }}$ and $4^{\text {th }}$ 
$\mathrm{hr}$ in comparison with the diabetic mice treated with the reference anti-diabetic drug. While treatment of diabetic mice with $300 \mathrm{mg} / \mathrm{kg}$ of total ethanolic fruit extract of $F$. albida caused a significant $(p<0.05)$ reduction in the blood glucose level at the $3^{\text {rd }}$ and $4^{\text {th }}$ hr in comparison with the diabetic mice treated with glimepiride.

The maximal reduction in blood glucose level $(74 \%)$ was observed at the $4^{\text {th }} \mathrm{hr}$ after oral administration of $200 \mathrm{mg} / \mathrm{kg}$ of the plant's extract, while glimepiride produced its maximal reductions $(55.2 \%)$ in blood glucose levels at the $4^{\text {th }} \mathrm{hr}$ post-administration (Table $1)$.

The percentage reduction in the blood glucose levels was calculated according to the following equation and the results are shown in figure 1.

$\%$ Glycemic change $=$

Glucose concentration after time (hrs) Fasting blood glucose Fasting blood glucose

Table 1: Effect of different doses of the total ethanolic fruit extracts of $F$. albida and glimepiride (2.5 $\mathrm{mg} / \mathrm{kg}$ ) on the blood glucose concentration $(\mathrm{mg} / \mathrm{dl})$ in NA-STZ diabetic mice.

\begin{tabular}{|c|c|c|c|c|c|c|}
\hline \multirow{2}{*}{ Groups } & \multirow{2}{*}{$\begin{array}{c}\begin{array}{c}\text { Before } \\
\text { treatment }\end{array} \\
0 \text { hour }\end{array}$} & \multicolumn{4}{|c|}{ After treatment } & \multirow{2}{*}{$\begin{array}{c}\% \text { maximal } \\
\text { reduction }\end{array}$} \\
\hline & & 1 hour & 2 hour & 3 hour & 4 hour & \\
\hline $\begin{array}{l}\text { Control non- } \\
\text { diabetic }\end{array}$ & $95.8 \pm 1.6$ & $94.3 \pm 1.5$ & $95.3 \pm 1.2$ & $95.6 \pm 1.6$ & $95 \pm 0.6$ & --- \\
\hline $\begin{array}{l}\text { Control } \\
\text { diabetic } \\
\end{array}$ & $441.7 \pm 31.9 *$ & $458.3 \pm 29.8^{*}$ & $466.7 \pm 28.8^{*}$ & $475 \pm 27.9^{*}$ & $483.3 \pm 27 *$ & --- \\
\hline $\begin{array}{c}\text { Glimepiride } \\
2.5 \mathrm{mg} / \mathrm{kg}\end{array}$ & $353.3 \pm 35$ & $345 \pm 36^{* *}$ & $308.3 \pm 27 * *$ & $235.7 \pm 35.9 * *$ & $158.3 \pm 27.1 * *$ & $55.2 \%$ \\
\hline TF-1 & $448.7 \pm 33.3$ & $253 \pm 25.1$ & $196 \pm 22.1^{\mathrm{a}}$ & $165.7 \pm 14^{\mathrm{a}}$ & $156 \pm 16.3^{\mathrm{a}}$ & $65.2 \%$ \\
\hline TF-2 & $478 \pm 27.9$ & $260 \pm 39.1$ & $166.7 \pm 27.7^{\mathrm{a}}$ & $138 \pm 28.3^{\mathrm{a}}$ & $124.2 \pm 28.7^{\mathrm{a}}$ & $74 \%$ \\
\hline TF-3 & $480 \pm 27.9$ & $308.7 \pm 8.7$ & $275.2 \pm 11.6$ & $197.8 \pm 10.8^{\mathrm{a}}$ & $148.2 \pm 10.6^{\mathrm{a}}$ & $69.1 \%$ \\
\hline
\end{tabular}

Values given represent the mean $( \pm \mathrm{S}$.E) of 6 observations $(\mathrm{n}=6, * p<0.05$ vs control non-diabetic; $* * p<0.05$ vs control diabetic; ${ }^{\mathrm{a}} p<0.05$ vs glimepiride).

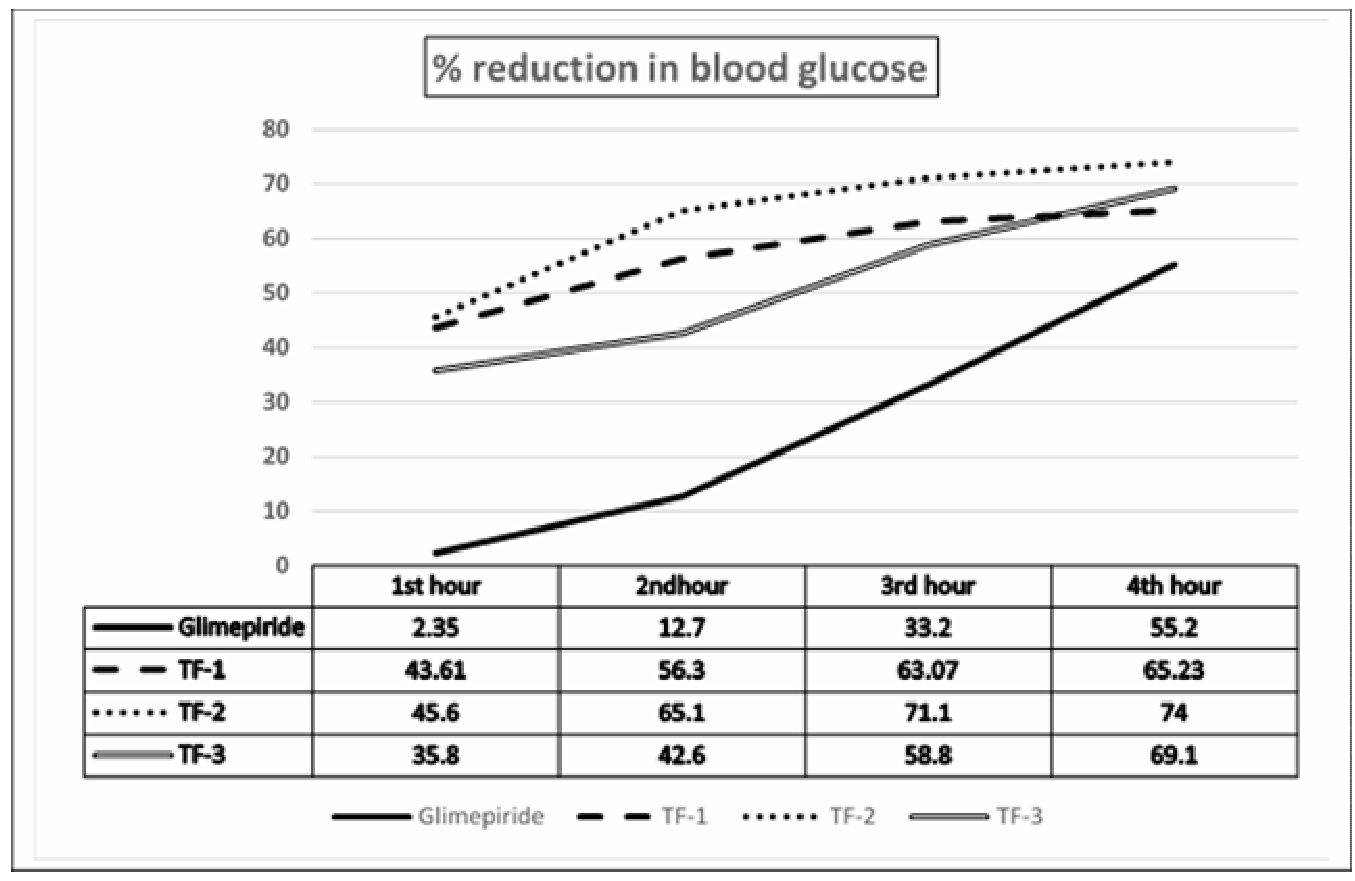

Fig. 1: Percentage reduction in blood glucose in NA-STZ diabetic mice treated with glimepiride and different doses of total ethanolic fruit extract. 


\section{Discussion}

Diabetes mellitus is a serious and distressing medical disorder affecting millions of people worldwide. The International Diabetes Federation estimated that 7.5 million individuals have diabetes and around 2.2 million have prediabetes in Egypt. Furthermore, reports indicate that $43 \%$ of patients with diabetes, and most patients with prediabetes in Egypt are likely undiagnosed ${ }^{19}$. Many herbal medicines have been recommended for the treatment of DM. Faidherbia albida is one of the medicinal plants that has proven efficacy in reducing the blood glucose levels in diabetic patients. In the current study, the possible anti-hyperglycemic effect of the total ethanolic fruit extract of $F$. albida was evaluated in a type 2 model of diabetes in mice with glimepiride as a standard antidiabetic drug. To ensure that the tested extract is devoid of toxicity at the doses consumed, an acute toxicity study was carried out.

Previous acute toxicity studies showed that different parts of the plant extract are relatively safe ${ }^{20 \& 21}$. However, nothing was reported about the safety of the fruit extracts. No mortality was observed in the animals treated by any of the doses in phase 1 within the $24 \mathrm{hrs}$ of observation. Mortality was observed in the animals treated by the selected doses in phase 2, which indicates that the extract is safe at doses up to $1600 \mathrm{mg} / \mathrm{kg}$.

Induction of DM in this study was done by a combination of streptozotocin and nicotinamide in adult mice. Nicotinamide is an antioxidant which exerts a protective effect on the cytotoxic action of STZ by scavenging free radicals and causing only minor damage to pancreatic beta-cell mass, hence producing type 2 diabetes. The elevated blood sugar level was observed to be moderate $(200 \pm 8 \mathrm{mg} / \mathrm{dL})$ and this can be attributed to the role of NA during the development of T2DM ${ }^{22}$.

Table 1 shows the effect of total ethanolic fruit extract of $F$. albida on nicotinamidestreptozotocin-induced diabetes mellitus in mice using 100, 200, and $300 \mathrm{mg} / \mathrm{kg}$ and glimepiride $2.5 \mathrm{mg} / \mathrm{kg}$ on blood glucose concentrations. The maximal reductions in the blood glucose concentration occurred at the dose of $200 \mathrm{mg} / \mathrm{kg}$, using the plant's extract at the $4^{\text {th }} \mathrm{hr}$ after the oral administration. While the reference antidiabetic drug glimepiride 2.5 $\mathrm{mg} / \mathrm{kg}$ produced significant reductions $(p<$ 0.05) in the blood concentration of the animals at the $1^{\text {st }} \mathrm{hr}$ following oral administration, reaching the peak of its hypoglycemic effect at the $4^{\text {th }} \mathrm{hr}$ after oral administration.

In line with our results, Murthy et al. (2013) reported that glimepiride exhibited its peak hypoglycemic activity at the $4^{\text {th }} \mathrm{hr}$ after oral administration. This can be attributed to the rapid stimulation of insulin secretion and increasing the peripheral insulin sensitivity by glimepiride ${ }^{23}$.

In accordance with the results of the present study supporting the antihyperglycemic properties of the fruit extract of F. albida, Salisu et al. (2009) reported that the methanolic root extract of $F$. albida reduced the blood glucose level of alloxan-diabetic rats using 100,200 , and $300 \mathrm{mg} / \mathrm{kg}$ compared with chlorpropamide $250 \mathrm{mg} / \mathrm{kg}$. The authors reported that the maximal reductions in the blood glucose concentration occurred at the dose of $200 \mathrm{mg} / \mathrm{kg}$, using the plant's extract at the $7^{\text {th }} \mathrm{hr}$ after the oral administration ${ }^{13}$.

Moreover, the findings of the present study are in line with the findings of a previous study conducted by Umar et al. (2014) who evaluated the anti-hyperglycemic and antihyperlipidemic effects of aqueous stem bark extract of $F$. albida in alloxan-induced diabetic rats compared with glibenclamide as a reference antidiabetic drug. Umar and his colleagues concluded that the investigated aqueous stem bark extract of $F$. albida exhibited a significant anti-hyperglycemic activity evidenced by a reduction in fasting blood glucose level in a dose-dependent manner. The authors concluded that the relationship between the anti-hyperglycemic properties of the extract was attributed to increase insulin secretion, improve glucose uptake by peripheral tissues, and reduce glucose absorption from the intestine ${ }^{15}$. These results agree with previous work on the effect of crude extract and fractions of the stem bark of $F$. albida on alloxan-induced diabetic rats ${ }^{16}$.

The anti-hyperglycemic activity of $F$. albida could be attributed to the insulinmimetic activity of some plant constituents such as terpenoids, flavonoids, and phenolics ${ }^{24}$. In a previous study conducted by Mohammed et al. (2018), rutin, quercetin, and luteolin were 
isolated from the fruits of $F$. albida $a^{25}$. Oral administration of rutin was found to exhibit significant anti-diabetic activity by inhibiting inflammatory cytokines as tumor necrosis factor- $\alpha$ and interleukin- 6 which are associated with insulin resistance. Rutin also improved the antioxidant and the plasma lipid profiles in high-fat diet + streptozotocin-induced type 2 diabetic rat model ${ }^{26}$. Ghorbani, (2017) reported additional proposed mechanisms for the antihyperglycemic effects of rutin including decreased absorption of carbohydrates from the small intestine, inhibition of tissue gluconeogenesis, increase of tissue glucose uptake, stimulation of insulin secretion from beta cells, and protecting Langerhans islet against degeneration ${ }^{27}$. Rutin also decreases the formation of sorbitol, reactive oxygen species, advanced glycation end-product precursors, and inflammatory cytokines. Moreover, oral administration of rutin was found to decrease plasma glucose, increase insulin levels, and restore glycogen content and hexokinase activity in diabetic rats ${ }^{28}$.

Quercetin - a powerful flavonoid in the $F$. albida fruits can increase hepatic glucokinase activity by increasing insulin secretion from pancreatic $\beta$ cells $^{29}$. Eid and Haddad, (2017) mentioned the pleiotropic mechanisms of action of quercetin that involve the inhibition of intestinal glucose absorption, insulin secretory, and insulin-sensitizing activities as well as improved glucose utilization in peripheral tissues ${ }^{30}$.

Another possible mechanism followed by flavonoid compounds to control blood glucose levels is the inhibition of $\alpha$-glucosidase activity in the intestine which mediates intestinal glucose absorption. Such inhibitory effects against $\alpha$-glucosidase activity were observed with luteolin ${ }^{28}$. Kim et al. (2000) reported that luteolin inhibited alpha-glucosidase stronger than acarbose ${ }^{31}$.

\section{Conclusion}

In conclusion, the results of the study showed that the total ethanolic fruit extract of F. albida possesses anti-hyperglycemic activity compared to glimepiride. This recommends its use as an anti-hyperglycemic agent in diabetic patients due to the presence of active ingredients as rutin, quercetin, and luteolin.

\section{Acknowledgements}

The authors acknowledge the animal house of Assiut University for providing the experimental animals.

\section{REFERENCES}

1- American Diabetes Association, "Diagnosis and Classification of Diabetes Mellitus", Diabetes Care, 33 (Suppl 1), 2010, pp. S62-S69.

2- S. Jeffrey and D. O. Freeman, "A physiologic and pharmacological basis for implementation of incretin hormones in the treatment of type 2 diabetes mellitus", Mayo. Clin. Proc., 85, S5-S14 (2010).

3- P. Modi, "Diabetes beyond insulin: Review of new drugs for treatment of diabetes mellitus", Curr. Drug Discov. Technol., 4, 39-47 (2007).

4- C. L. Triplitt and C. A. Reasner, "Chapter 83: Diabetes mellitus". In: J. T. DiPiro, R. L. Talbert, G. C. Yee, G. R. Matzke, B. G. Wells, L. M. Posey, Pharmacotherapy: A Pathophysiologic Approach, $8^{\text {th }}$ Edn., New York, NY: McGraw-Hill., 2011, p. 1274.

5- S. L. Vishwakarma, R. D. Sonawane, M. Rajani and R. K. Goyal, "Evaluation of effect of aqueous extract of Enicostemma littorale Blume in streptozotocin-induced type 1 diabetic rats", Indian J. Exp. Biol., 48, 26-30 (2010).

6- A. Gurib-Fakim, "Medicinal plants, Traditions of yesterday and drugs of tomorrow", Mol. Aspects Med., 27, 1-93 (2006).

7- I. H Al-Gohary and A. H. Mohamed, "Seed morphology of Acacia in Egypt and its taxonomic significance", Int. J. Agric. Biol., 9, 435-438 (2007).

8- P. J. Wood, "The Botany and Distribution of Faidherbia albida", Proceedings of the workshop on Faidherbia albida in the West African Semi-Arid Tropics, Niamey, Niger., 1992, pp. 9-17.

9- A. Y. Tijani, M. O. Uguru and O. A. Salawu, "Anti-pyretic, anti-inflammatory and anti-diarrhoeal properties of Faidherbia albida in rats", Afr. J. Biotechnol., 7, 696-700 (2008).

10- W. A. Usman, S. J. Mahmoud and Z. H. Ahmed, "Antimicrobial activity of stem bark of Faidherbia albida", Br. J. Pharmaceut. Res., 3, 786-794 (2013). 
11- T. S. Shinkafi, L. Bello, S. W. Hassan and S. Ali, "An ethnobotanical survey of antidiabetic plants used by Hausa-Fulani tribes in Sokoto, North west Nigeria", $\boldsymbol{J}$. Ethnopharmacol., 172, 91-99 (2015).

12- A. Mohammed, M. A. Ibrahim and S. Islam, "African medicinal plants with antidiabetic potentials: A review", Planta Med., 80, 354-377 (2014).

13- Y. Salisu, A. Agunu, M. S. Abubakar and G. Ibrahim, "Hypoglycaemic effects of Faidherbia albida Del. (Mimosaceae) methanol root bark extract", Niger. J. Pharm. Sci., 8, 66-72 (2009).

14- K. E. Gaber, U. Singhal and O. Daowd, "Hypoglycaemic and hypolipidaemic effects of some common plants extract in type 2 diabetic patients at Eldabba area (North Sudan)", IOSR J. Pharmac. Biol. Sci., 8, 38-43 (2013).

15- I. A. Umar, A. Mohammed, U. S. Ndidi, A. B. Abdulazeez, W. C. Olisa and M. Adam, "Anti-Hyperglycemic and antihyperlipidemic effects of aqueous stem bark extract of Faidherbia albida Delile in alloxan induced diabetic rats", Asian J. Biochem., 9 (4), 170-178 (2014).

16- A. J. Kashimawo, J. A. Kolawole and J. O. Kemelayefa, "Antidiabetic activity of the stem bark extract and fractions of Faidherbia albida Del. (Mimosaceae) in murine model", IOSR J. Pharm. Biol. Sci. (IOSR-JPBS), 12, 26-30 (2017).

17- D. Lorke, "A new approach to practical acute toxicity testing", Arch. Toxicol., 54, 275-287 (1983).

18- A. Ahangarpour, F. R. A. Akbari and H. F. Moghadam, "Effect of C-peptide alone or in combination with nicotinamide on glucose and insulin levels in streptozotocin-nicotinamide-induced type 2 diabetic mice", Malays J. Med. Sci., 21, 12-17 (2013).

19- D. R. Whiting, L. Guariguata, C. Weil, et al., "IDF diabetes atlas: Global estimates of the prevalence of diabetes for 2011 and 2030", Diabetes Res. Clin. Pract., 94, 311-321 (2011).

20- O. A. Salawu, A. Y. Tijani, H. Babayi, R. A. Anagbogu and V. A. Agbakwuru, "Anti-malarial activity of ethanolic stem bark extract of Faidherbia albida (Del.) A. Chev (Mimosaceae) in mice", Arch. Appl. Sci. Res., 2, 261-268 (2010).
21- A. R. Lawal, A. Agunu, H. Ibrahim and K. Ibrahim, "Acute toxicity and pharmacognostic studies of the root bark of Faidherbia albida Del. (Fabaceae)", Niger. J. Pharm. Sci., 11, 31-38 (2012).

22- P. Masiello, C. Broca, R. Gross, M. Roye, M. Manteghetti and D. Hillaire-Buys, "Experimental NIDDM: Development of new model in adult rats administered streptozotocin and nicotinamide", Diabetes, 47, 224-229 (1998).

23- T. E. G. K. Murthy, M. K. Kommineni and C. Mayuren, "Influence of losartan on the hypoglycemic activity of glimepiride in normal and diabetic rats", Ther. Adv. Endocrinol. Metab., 4, 133-138 (2013).

24- D. Patel, S. Prasad, R. Kumar and S. Hemalatha, "An overview on antidiabetic medicinal plants having insulin mimetic property", Asian Pacific Journal of Tropical Biomedicine, 2, 320-330 (2012).

25- M. M. Mohammed, A. A. Ali, E. Desoky and L. G. Gobraeil, "Compounds isolation and antioxidant activity of Faidherbia albida fruit extract", Int. J. Chem. Stud., 2, 35-40 (2018).

26- N. T. Niture, A. A. Ansari and S. R. Naik, "Anti-hyperglycemic activity of rutin in streptozotocin-induced diabetic rats: An effect mediated through cytokines, antioxidants and lipid biomarkers", Indian J. Exp. Biol., 52, 720-727 (2014).

27- A. Ghorbani, "Mechanisms of antidiabetic effects of flavonoid rutin", Biomed. Pharmacother., 96, 305-312 (2017).

28- G. Brahmachari, "Bio-flavonoids with promising antidiabetic potentials: A critical survey", Opportunity, Challenge and Scope of Natural Products in Medicinal Chemistry, 2, 187-212 (2011).

29- M. Vessal, M. Hemmati and M. Vasei, "Antidiabetic effects of quercetin in streptozocin-induced diabetic rats", Comp. Biochem. Physiol. C Toxicol. Pharmacol., 135, 357-364 (2003).

30- H. M. Eid and P. S. Haddad, "The antidiabetic potential of quercetin: Underlying mechanisms", Curr. Med. Chem., 24, 355-364 (2017).

31- J. S. Kim, C. S. Kwon and K. H. Son, "Inhibition of alpha-glucosidase and amylase by luteolin, a flavonoid", Biosci. Biotechnol. Biochem., 64, 2458-2461 (2000). 


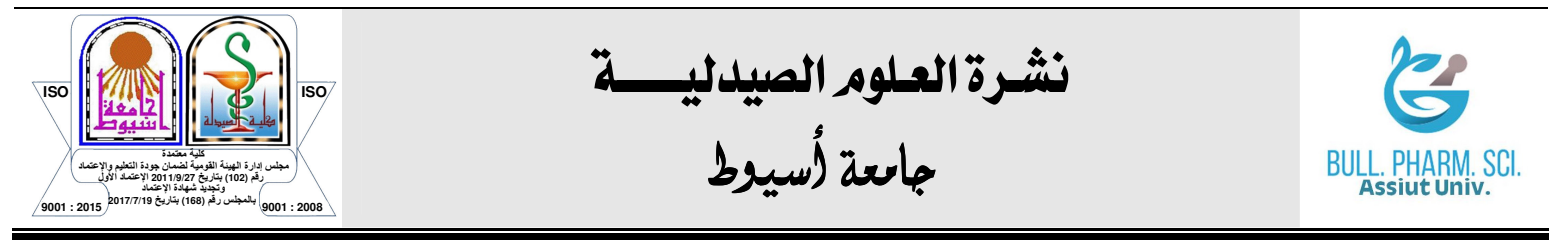

\section{التأثير المضاد لفرط سكر الام لخلاصة الإيثانول الكلية لثمرات نبات فايدهربيا البيدا في الفئران المصابة باءاء السكري التي يسبيها النيكوتيناميد والستربتوزوتوسينين

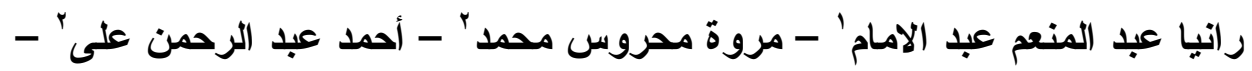

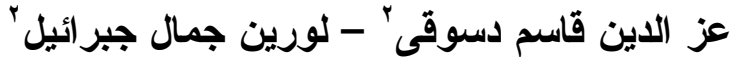

'قسم الفارماكولوجى ، كلية الطب ، جامعه أسيوط، أسيوط 1010 10 ، مصر

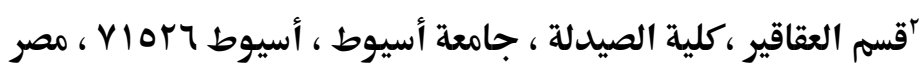

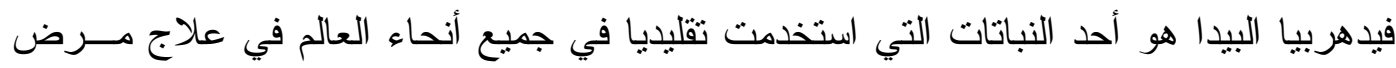

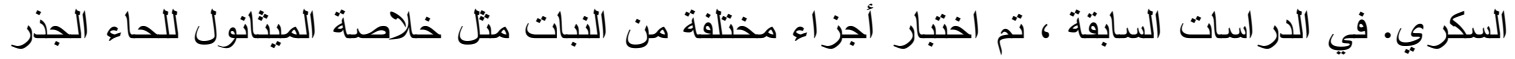

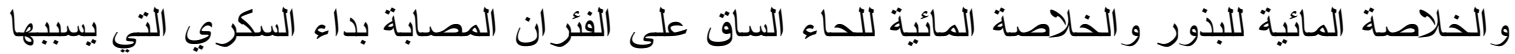

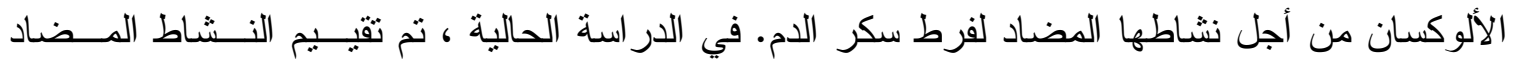

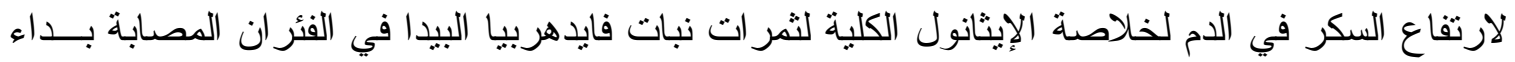

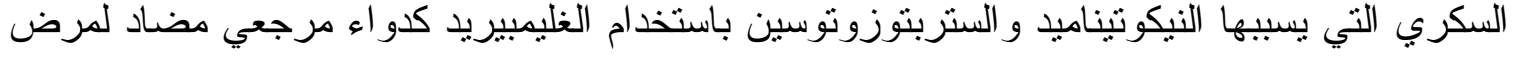

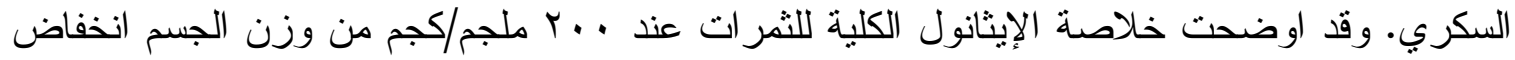

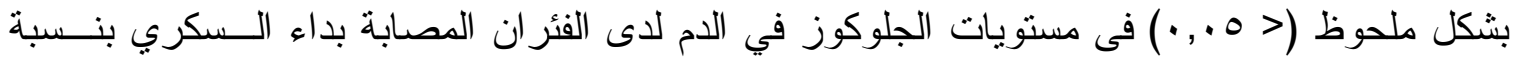

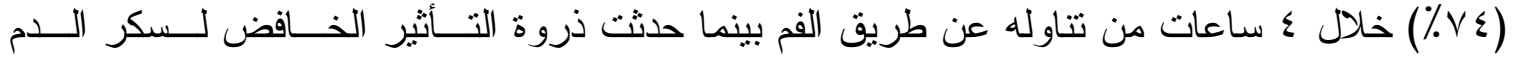

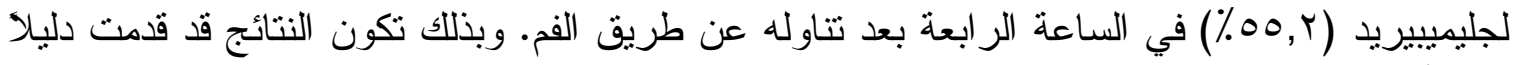

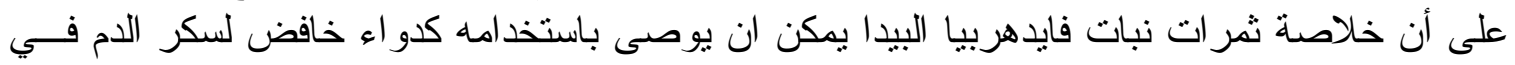
علاج مرضى السكري. 